\title{
Acting and Thinking as a Revolutionary Organ: The Case of the French Review Socialisme ou Barbarie (1948-1965)
}

\author{
Christophe Premat \\ Stockholm University, Stockholm, Sweden
}

\begin{abstract}
The aim of the article is to analyze the evolution of a radical left group in France that created a scission inside the Fourth International after World War II. The group founded a review Socialisme ou Barbarie that criticized Marxism and the Trotskyist interpretation of the status of the USSR. The rigorous description of this review reveals the mixture of strong theoretical views on bureaucratic societies and empirical investigations of reactions against those societies. The hypothesis is that this group failed to be a new political force. As a matter of fact, is it possible to depict the evolution of Socialisme ou Barbarie as an investigative journalism based on a strong political and philosophical theory?
\end{abstract}

Keywords: Bureaucratic societies, Sovietologist, investigative journalism, Socialisme ou Barbarie, Castoriadis, political periodicals

\section{Introduction}

The review Socialisme ou Barbarie is a political act refusing the Trotskyist interpretation of the USSR regime as a degenerated worker State. It comes from an ideological scission inside the Fourth International and was cofounded by the Greek exilé Cornelius Castoriadis and Claude Lefort. It is characterized by an early understanding of the nature of the USSR. Socialisme ou Barbarie is first a tendency inside the Fourth International before being a review and a real revolutionary group.

The review existed from 1948 until 1965 whereas the group Socialisme ou Barbarie continued to exist until 1967. The review was considered as a space for a political debate, the members shared the idea that the USSR was a strong failure for the workers' movement. The idea of Castoriadis was to analyze the reasons explaining this failure as the Socialists have to struggle against capitalistic societies and the USSR. It is why the members of Socialisme ou Barbarie lived in an ideological marginality in the postwar France. This review had a real political meaning, some of the articles were debated by an editorial committee, it mixed some empirical analyzes with a strong theoretical point of view of international relations. Socialisme ou Barbarie presented its main goals through a Manifesto, rewriting the Communist Manifesto of Marx. The review and the group wanted to save the idea of socialism as well as the rhetoric of socialism.

One century after the Communist Manifesto, thirty years after the Russian Revolution, after huge victories and deep defeats, the revolutionary movement seems to have disappeared, like a river, which, by getting near to the sea, results in swamps and vanishes in the sand. (Castoriadis, 1973, p. 139)

Christophe Premat, Lecturer in French Cultural Studies, Department of Romance Studies and Classics, Stockholm University. 
The image is really stronger especially when the Manifesto refers to the concentration camps of the USSR. The image of dryness is striking as the socialist ideas can disappear with this strong falsification that existed in the USSR. The Manifesto is like a political tribute to the revolutionary movement that can have a future outside bureaucratic societies. This State has repressed the revolutionary movement and the idea of Socialisme ou Barbarie is to secure the revival of the Socialist ideas in order to reach the proletariat's emancipation. What does the Socialist revolution mean for the cofounders of the review and its members? Are there new political ideas to promote in order to claim this revival? The hypothesis here is that the periodical turned to be an investigative and theoretical review, especially when it failed to become a revolutionary power at the end of the fifties. The authors themselves would certainly not accept be included in the genre of investigative journalism, but the marginality of the review gave this possibility of creating this platform. Furthermore, by focusing on the evolution of USSR, the review became a Sovietologist review with a deep analysis of the regime. As Cramerotti wrote, "journalism is intended to be a service in the interest of the highest number of people possible, not an opportunity to influence decisions and gain power" (Cramerotti, 2009, p. 22). The idea of investigative journalism is more linked to the professionalization of actors that dismantle the hidden mechanisms of some political and economical scandals (Marchetti, 2000, p. 32). Here, the turnover of the review after the strong debates on its political profile among the members is an opportunity for this reorientation.

To be able to discuss the evolution of the review style, the political diagnostic of Socialisme ou Barbarie will be presented. Then, the organization of the review is worth being studied as it has consequences on the debates among the members. Who writes in this review and what for? Is it just a platform for Castoriadis' ideas or is there a real cooperation? The last part of the articles focuses on the international relations between Socialisme ou Barbarie and other political periodicals that share similar debates.

The perspective of social anthropology is needed here to study the networks and practices of revolutionary militant that also acted as investigative journalists to deepen and justify their own theories. The aspect of "memory practices" (Hurdley, 2013, p. 12) is relevant to understand a revolutionary group as a socialization of outsiders that could develop a relevant theory of societies. There is an "epistemological advantage" (Dosse, 2015) in this posture as the outsiders are aware of the deep mechanisms of social domination. It is difficult to analyze how people reacted to this intellectual journal as it is impossible to make an ethnography of the readers (Bird, 2010). The review was a political platform from radical left thinkers promoting the idea of autonomy. In other words, it was a reference for the individuals and periodicals that shared this project.

\section{State of the Art}

Three main works were published on Socialisme ou Barbarie, the book of Philippe Gottraux that focused on the relation between Castoriadis' work and his experience as a revolutionary militant (Gottraux, 1997), the thesis of Marie-France Raflin (Raflin, 2005) on the conception of Socialisme ou Barbarie and the cultural historical work of Francois Dosse that focused more on the generational influence of Socialisme ou Barbarie (Dosse, 2014) inside a book dedicated to the intellectual figure of Cornelius Castoriadis. Whereas Raflin and Dosse pointed out the symbolic existence of the theoretician Castoriadis with this group, Gottraux distinguished two sides of Castoriadis' public existence, the one as a revolutionary militant from 1948 until 1964 and then the second one as a philosopher and psychoanalyst from 1964 to 1997 (Gottraux, 1997). David Ames Curtis 
questioned this point of view as there is a strong coherence of Castoriadis' trajectory (Curtis, 1997, pp. X-XI). There is a theoretical unity as he already had a view of bureaucratic relations in the forties. The review and the group were also closely linked to the experience of exile of Castoriadis (Premat, 2004; Jollivet, Rosengren, \& Premat, 2011). By fleeing the situation in Greece where the civil war turned to be a shock between the Eastern and Western regimes, Castoriadis was aware of the necessity of redefining socialism. The views on the international situation were illustrated by many empirical investigations. Some comrades of Socialisme ou Barbarie gave some interesting testimonies on meaningful events such as strikes or rebellions, they also described the social life of workers (Mothé, 1959). The case of Daniel Mothé who was member of Socialisme ou Barbarie and worked in Renault is important as Daniel Mothé presented the everyday life of workers. The thoughts of former members of Socialisme ou Barbarie are also important as they illustrate the internal debates and the difficulties of a far-left group that was marginalized (Lyotard, 1989).

\section{The Political Diagnostic of Socialisme ou Barbarie}

What is striking with the political experience of Socialisme ou Barbarie is the very early diagnostic on the evolution of the USSR, especially in the postwar context in France where the USSR had a real positive image (Premat, 2004, p. 105). At first sight, there is a Marxist rhetoric but in 1948, there is a rupture with Marxism even if the style is still influenced by a leftist language. This diagnostic was possible because of the early experience of the absurdity of the cold war by Cornelius Castoriadis who flew Greece with the help of the French Institute of Athens and his director, Octave Merrier (Millie, 1996, p. 80). As a Greek exilé, Castoriadis was aware of Stalinism and the perversion of the Proletarian revolution by the epigones of the USSR.

For my part, I had been developing a critique of the Trotskyist conception of Stalinism since late 1944/early 1945 on the basis of my experience of the December 1944/ January 1945 Stalinist coup d'état in Greece. For Trotsky and the Trotskyists, the Stalinist parties in the capitalist countries had lined up definitively on the side of the bourgeois order. (Castoriadis, 1997, p. 1)

Some other Greek exilés that flew the country at the same time as Castoriadis also developed an early consciousness of the nature of Stalinism. This was the case of Kostas Papaioannou who created a review and criticized the domination of a single bureaucratic apparatus in Eastern Europe. The orthodox Marxism was a truth that could not be questioned in the Soviet Union (Papaïoannou, 1969, p. 47). Papaïoannou shared with Castoriadis this critics of Marxism but did not have the same political diagnostic on the Western regime.

This position gave Castoriadis a lucidity on the reality of the cold war. The word "lucidity" is recurrent in his articles. Cornelius Castoriadis was born in 1922 and experienced politics when he joined the Trotskyist organization of Stinas in Greece (Chiclet, 1990, pp. 117-118). The country was under the dictatorship of Metaxas at that time. Then, Greece was the field of a war between the Greek Communist Party and the Monarchists supported by England. As a Trotskyist, Castoriadis was threatened from both sides as the Greek Communist Party sentenced to death many Trotskyists (Dosse, 2014, pp. 26-31). Greece was the experience of the absurdity of the cold war, Castoriadis noticed the Stalinism of the Greek Communist Party that did not want to take the power but remained strictly linked to the USSR. This civil war was due to a shock between bureaucratic regimes that contradicted the workers' interests. He flew Athens with 180 Greek intellectuals in December 1945 on a boat called Mataroa with the help of the French Institute of Athens (Jollivet, Rosengren, \& Premat, 2011). This exile gave him an accurate feeling of what Communism was. For him, it was obvious 
that Communism was a name for a bureaucratic organization that was against the emancipation of workers. He perceived USSR as a deep lie on socialism as USSR was a totalitarian State. When he arrived in France in 1946, his voice could not be heard as he was rejecting both the Capitalist and the Communist systems. He was convinced that the cold war was not an alternative between two social projects but a formal difference between regimes that aimed at repressing the workers' autonomy.

This position of outsider explained that his thought could be later on rediscovered from thinkers that did not want to be prisoners from this geopolitical interpretation. In Postwar France, the ideological and political climate was dominated by the positive perception of the USSR. The French Communist Party had around 30\% of votes and many French citizens saw USSR as one of the heroes of the Second World War (Premat, 2004, pp. 103-123). Castoriadis joined the Fourth International in France which was the organ of Trotskyists. He wanted to continue with politics and proposed a new diagnostic on the geopolitical transformations. At that time Claude Lefort was receptive to these arguments and formed with Castoriadis and a few comrades a tendency inside the Fourth International.

He also anticipated the failure of Trotskyism which renounced to define the USSR as a new bureaucratic form. According to the Trotskyists from the Fourth International, USSR was a degenerated worker State. Trotskyists were afraid to criticize the USSR in a radical way as they were attached to the Soviet experiences in the first months of the Russian Revolution of 1917. On the contrary, Castoriadis and Lefort, it was clear that the USSR was another social project, a total form of bureaucracy where order-takers and order-givers were completely separated. The difference with the Capitalist regimes was that the order-givers were a new class with individuals coming from the Communist party. The reproduction of the dominating class was replaced by a new stratum of individuals that had the legitimacy by the pure fact of belonging to the Communist party. The tendency of Castoriadis/Lefort (they used pseudonyms at that time with Chaulieu/Montal) decided to quit the Fourth International and created a group and a review called Socialisme ou Barbarie. The alternative is between the regimes that focus on the socialization of directive tasks and the others that separate order-givers from order-takers. This diagnostic revealed a strong lucidity from Castoriadis, a word that regularly appears in different works from Castoriadis. François Dosse deals with the notion of epistemological advantage that comes from the exile. As a Greek exile, he really experienced the absurdity of Stalinism (Jollivet, Rosengren, \& Premat, 2011, p. 19). Castoriadis began to read philosophy at a very early age when he was thirteen. This precocity helped him to develop a theoretical frame to analyze the evolution of Greece under the dictatorship of Metaxas (1936-1941) and the collapse of the bourgeois-liberal parties (Memos, 2014, p. 16). When he came to France, he already had a geopolitical analysis that would not fit the classical Marxist frame that was dominating at that time in France.

His first rupture with Trotskyism was about the link to the USSR. If people realized that the USSR was a collection of lies that is contradictory to Socialism, then it would help the workers to emancipate from the Bureaucrats. The Bureaucrats are the new order-takers that reinforced the social structure of capitalism by making true the strict separation between order-takers and order-givers. Castoriadis became a Sovietologist by analyzing the evolution of this social regime. It is important for people who fight for Socialism to understand the nature of this regime. Castoriadis translated in the number four of Socialisme ou Barbarie an article of Peregrinus on the Russian Kohlkoz (Chaulieu, 1949, pp. 3-18). Many articles concerned the nature of the political events in the USSR. The events in Hungary in 1956 were debated and discussed among the members of the review and the group. Table 1 shows the articles that concerned the Soviet Union. 
Table 1

Articles on the USSR in the Review Socialisme ou Barbarie

\begin{tabular}{|c|c|c|}
\hline \begin{tabular}{|l|} 
Socialisme ou \\
Barbarie
\end{tabular} & Year & Name of the article \\
\hline Number 2 & 1949 (May-June) & "Les rapports de production en Russie" \\
\hline Number 2 & 1949 (May-June) & "Défaitisme révolutionnaire ou défaitisme stalinien" \\
\hline Number 2 & 1949 (May-June) & "La situation internationale" \\
\hline Number 2 & 1949 (May-June) & “Le procès Kravchenko" \\
\hline Number 3 & 1949 (July-August) & "Stakhanovisme ou mouchardage dans les usines tchécoslovaques" \\
\hline Number 3 & 1949 (July-August) & "La consolidation temporaire du capitalisme mondial" \\
\hline Number 4 & 1949 (October-November) & “Les Kohlkoz pendant la guerre" \\
\hline Number 4 & 1949 (October-November) & "L'exploitation des paysans sous le capitalisme bureaucratique" \\
\hline Number 4 & 1949 (October-November) & "la situation internationale" \\
\hline Number 4 & 1949 (October-November) & "Les répercussions de l'explosion atomique russe" \\
\hline Number $5 / 6$ & 1950 (March-April) & "La guerre et notre époque (suite)" \\
\hline Number $5 / 6$ & 1950 (March-April) & "la situation internationale" \\
\hline Number 7 & 1950 (August-September) & "Le stalinisme en Allemagne orientale" \\
\hline Number 7 & 1950 (August-September) & "Machinisme et prolétariat" \\
\hline Number 7 & 1950 (August-September) & "Le procès Kalandra" \\
\hline Number 8 & 1951 (January-February) & "Le stalinisme en Allemagne orientale" \\
\hline Number 8 & 1951 (January-February) & "La situation internationale" \\
\hline Number 9 & 1952 (April-March) & "La guerre et la perspective révolutionnaire" \\
\hline Number 10 & 1952 (July-August) & “"Trotskysme et stalinisme” \\
\hline Number 11 & 1952 (November-December) & "La situation internationale" \\
\hline Number 12 & 1953 (August-September) & "la situation internationale" \\
\hline Number 12 & 1953 (August-September) & “les syndicats soviétiques" \\
\hline Number 13 & 1954 (January-March) & “1953 et les luttes ouvrières" \\
\hline Number 13 & 1954 (January-March) & "Signification de la révolte de 1953 en Allemagne orientale" \\
\hline Number 13 & 1954 (January-March) & "Le prolétariat d'Allemagne orientale après la révolte de juin 1953" \\
\hline Number 13 & 1954 (January-March) & "Sur la dynamique du capitalisme" \\
\hline Number 14 & 1954 (April-June) & "Situation de l'impérialisme et perspectives du prolétariat" \\
\hline Number $15 / 16$ & 1954 (October-December) & "La bombe H et la guerre apocalyptique" \\
\hline Number 17 & 1955 (July-September) & "Sur le contenu du socialisme" \\
\hline Number 17 & 1955 (July-September) & "La nouvelle diplomatie russe" \\
\hline Number 18 & 1956 (January-March) & "La situation internationale" \\
\hline Number 19 & 1956 (July-September) & "Le totalitarisme sans Staline - L'URSS dans une nouvelle phase" \\
\hline Number 19 & 1956 (July-September) & "Khrouchtchev et la décomposition de l'idéologie bureaucratique" \\
\hline Number 19 & 1956 (July-September) & "la déstalinisation dans les démocraties populaires" \\
\hline Number 19 & 1956 (July-September) & "le PCF après le XXe Congrès" \\
\hline Number 19 & 1956 (July-September) & "Rideau sur la métaphysique des procès" \\
\hline Number 20 & 1956-(December-February 2017) & "Les impérialismes et 1’Egypte de Nasser" \\
\hline Number 20 & 1956-(December-February 2017) & "La révolution en Pologne et en Hongrie" \\
\hline Number 20 & 1956-(December-February 2017) & "L’insurrection hongroise" \\
\hline Number 20 & 1956-(December-February 2017) & "Comment ils se sont battus" \\
\hline Number 20 & 1956-(December-February 2017) & "Chez Renault, on discute de la Hongrie" \\
\hline Number 20 & 1956-(December-February 2017) & "La révolution prolétarienne contre la bureaucratie" \\
\hline Number 21 & 1957 (March-May) & "Bilan, perspectives, tâches" \\
\hline Number 21 & 1957 (March-May) & "Retour de Pologne" \\
\hline
\end{tabular}


(Table 1 continued)

\begin{tabular}{|c|c|c|}
\hline \begin{tabular}{|l} 
Socialisme ou \\
Barbarie
\end{tabular} & Year & Name of the article \\
\hline Number 21 & 1957 (March-May) & "La voie polonaise à la bureaucratisation" \\
\hline Number 21 & 1957 (March-May) & "Documents polonais" \\
\hline Number 21 & 1957 (March-May) & "Récits et textes sur la révolution hongroise" \\
\hline Number 21 & 1957 (March-May) & "Les conseils ouvriers de la révolution hongroise" \\
\hline Number 21 & 1957 (March-May) & "La restalinisation de la Hongrie" \\
\hline Number 22 & 1957 (July-September) & "Sur le contenu du socialisme" \\
\hline Number 22 & 1957 (July-September) & "La contre-révolution en Hongrie" \\
\hline Number 22 & 1957 (July-September) & “Six mois de kadarisation” \\
\hline Number 22 & 1957 (July-September) & "La situation en Pologne" \\
\hline Number 22 & 1957 (July-September) & "Le réveil des intellectuels et étudiants en URSS" \\
\hline Number 23 & 1958 (January-February) & "Sur le contenu du socialisme" \\
\hline Number 23 & 1958 (January-February) & "Devant le satellite artificiel russe" \\
\hline Number 23 & 1958 (January-February) & "Documents: Gabor Kocsis: sur les conseils ouvriers" \\
\hline Number 23 & 1958 (January-February) & "La situation en Hongrie" \\
\hline Number 23 & 1958 (January-February) & "La révolution qui vient" \\
\hline Number 24 & 1958 (May-June) & "Pologne: la kadarisation froide" \\
\hline Number 26 & 1958 (November-December) & $\begin{array}{l}\text { "Remarques critiques sur la critique de la révolution russe de Rosa } \\
\text { Luxembourg" }\end{array}$ \\
\hline Number 26 & 1958 (November-December) & "Le monde en question" \\
\hline Number 27 & 1959 (April-May) & "Un nouveau rapport de Khrouchtchev" \\
\hline Number 28 & 1959 (July-August) & "Les livres: la classe ouvrière d’Allemagne orientale" \\
\hline Number 31 & 1960 (December-February 1961) & "Le mouvement révolutionnaire sous le capitalisme moderne" \\
\hline Number 32 & 1961 (April-June) & "Le mouvement révolutionnaire sous le capitalisme moderne" \\
\hline Number 33 & 1961 (December-February 1962) & "Le mouvement révolutionnaire sous le capitalisme moderne" \\
\hline Number 34 & 1963 (March-May) & "L'éducation sexuelle en URSS" \\
\hline Number 34 & 1963 (March-May) & "Le conflit sino-soviétique" \\
\hline Number 34 & 1963 (March-May) & "Accélération et contradictions du dégel en URSS" \\
\hline Number 35 & 1964 (January-March) & “"Recommencer la Révolution" \\
\hline Number 35 & 1964 (January-March) & "Le rôle de l’idéologie bolchévik dans la naissance de la bureaucratie" \\
\hline Number 35 & 1964 (January-March) & “Kollontaï: l’opposition ouvrière” \\
\hline Number 36 & 1964 (April-June) & "Marxisme et théorie révolutionnaire" \\
\hline Number 37 & 1964 (July-September) & "Marxisme et théorie révolutionnaire" \\
\hline Number 37 & 1964 (July-September) & "Le différend sino-soviétique" \\
\hline Number 38 & 1964 (October-December) & "Marxisme et théorie révolutionnaire" \\
\hline Number 38 & 1964 (October-December) & "La chute de Khrouchtchev" \\
\hline Number 39 & 1965 (March-April) & "L’homme révolutionné et l’homme révolutionnaire" \\
\hline Number 39 & 1965 (March-April) & "Le khrouchtchévisme sans Khrouchtchev" \\
\hline Number 40 & 1965 (June-August) & "Marxisme et théorie révolutionnaire" \\
\hline Number 40 & 1965 (June-August) & "Bureaucratie dominante et esclavage politique" \\
\hline
\end{tabular}

Note. Source: http://archivesautonomies.org/spip.php?article758 (Last visit: 21 June 2016).

Socialisme ou Barbarie published 38 numbers between 1949 and 1967 even if no numbers were published between summer 1965 and 1967. There is a sovietologist profile in the review especially after such events as 1953 in East-Germany and Hungary in 1956. Numbers 19 to 23 include many analysis on the USSR. Other articles include a point of view on the USSR from a general perspective on the Proletarian revolution. Some 
other articles ("Sur la révolution sexuelle en URSS") concern a book review or a specific witness on a sociological perspective in the USSR. 84 articles directly concerned the situation in the USSR. In all the numbers, notes on the international situation are published. Most of them commented the cold war. For instance, in 1949, when the Stalinian parties promoted the idea of peace to justify the strategy of the USSR.

The forms of defeatism are not reduced to the statement that "the enemy is in our country". In fact, this watchword has no more significance. The notion of country is more and more outdated, even from the bourgeois point of view. The next conflict will not happen between national bourgeoisies but between two forces that already shared the world and want to eliminate each other. This watchword looses its value if the military conditions of the modern war are taken into consideration"1.

The review and the group were also created to save the proletarian revolution and raise the question of truth. How can we use words such as revolution when the contrary - which means the repression of the social emancipation-happens? The struggle to rediscover the truth of the language is the most important thing. The bureaucratic institution of societies is dangerous as it threatens the language itself. If we use words that we do not mean, how can we have a dialogue and find a democratic platform?".

The Socialist or Stalinist party, in trying to persuade the proletariat that it represents its interests, is trying to deceive it but is not betraying it; they betrayed it once and for all a long time ago, and since they are not traitors to the working class but consistent and faithful servants of other interests. (Castoriadis, 1997, p. 41)

The solution is radical, Stalinism is not a mere degradation of the Revolution, it is an attempt to create a new stratum of order-givers that dominate the proletariat. This care for the truth of the USSR was all the more important as the members of the group wanted to save the idea of Socialism. The USSR was an assemblage of four lies as there is no union but a bureaucratic imperialism that had nothing to do with Socialism.

Forty years have elapsed since the proletarian revolution seized power in Russia. From that revolution it is not socialism that ultimately emerged but a new and monstrous form of exploiting society and totalitarian oppression that differed from the worst forms of capitalism only in that the bureaucracy replaced the private owners of capital and "the plan" took the place of the "free market". (Castoriadis, 1997, p. 49)

The originality of Castoriadis is due to the fact that he saw the Cold War as an expression of the same will, the bureaucratic institution of society. There is not a difference of nature between the Eastern and Western regimes but a difference of form. The Western regimes have fragmented bureaucracies with a few remaining civil liberties (freedom of speech, Constitution) whereas the Eastern regimes imposed a total control on social activities.

Modern capitalism is essentially a bureaucratized society with a pyramidal, hierarchical structure. In it are not opposed, as in two clearly separate tiers, a small class of exploiters and a large class of producers. The division of society is much more complex and stratified, and no simple criterion is available to sum it up. (Castoriadis, 1997, p. 119)

The diagnostic is even more radical when Castoriadis and Socialisme ou Barbarie claim that the ideal-type of Western regimes is Eastern regimes where the social control is total. The Western bureaucracies are more fragmented, it is complex to study the evolutions of the domination as there are still spaces for social contestation and freedom. The order-givers aim at eliminating those spaces of contestation. Unconsciously, they try to create the conditions of a total social control, a control on the production and a control on the work

\footnotetext{
1 "Défaitisme révolutionnaire et défaitisme stalinien", Socialisme ou Barbarie, n², May-June 1949, 115.
} 
force. Ideologies are used to hide the real state of social relations. Socialisme ou Barbarie is interested in the evolution of USSR for two reasons: the group wants to save the idea of socialism and the meanings of the word and the group wants to analyze the transformations of this total bureaucracy as it has an influence on the remaining Western regimes.

The review had a strong internal debate in 1958 with a discussion between Claude Lefort and Cornelius Castoriadis. According to Claude Lefort, Socialisme ou Barbarie could not become a political party as a party is a bureaucratic organization. Adopting this form would contradict the theoretical posture of the periodical. "Bureaucracy exists only by bureaucrats, by their common intention to create a separate environment, away from the dominated" (Lefort, 1971, p. 98). Lefort wanted to maintain a radical view on political organizations based on spontaneous actions. He left the group in 1958 but this internal debate affected the evolution of the periodical. Some comrades began to publish a parallel review, Pouvoir Ouvrier and devoted a lot of energy to the war in Algeria. Jean-François Lyotard, the founder of postmodernism, was one of them (Lyotard, 1990, p. 106). Two tendencies inside the group discussed different thesis and the orientation of the periodical, Castoriadis wanted to eliminate the Marxist rhetoric that was used whereas Lyotard and others did not want to change it. Castoriadis wanted to avoid some confusion generated by concepts that were perverted in the USSR. This turnover inside the organization created a last scission that was fatal. The last publications were in 1965 and the group disappeared in 1967, one year before the events of May 68. All those debates around the orientation and the common language of the group reflected a democratic vitality which was the platform for an investigative journalism.

\section{The Periodical as a New Way of Doing Politics}

The first numbers of Socialisme ou Barbarie dealt with the orientations of the review and the content of the program. The goal is the emancipation of the working class. The periodical is serious with a mixture of theoretical texts and investigations.

To say that we support unconditionally every proletarian struggle, that we are on the side of the workers at each moment they struggle to defend their interests, even if we are in disagreement over the definition of the objectives and of the means of struggle, is an elementary truth that goes without saying. But to want, apropos of every partial struggle, to give oneself over to superficial and sterile agitation for the General Strike or for the Revolution, despite all reality and all evidence, is a task we want nothing to do with. (Castoriadis, 1997, p. 38)

The review wanted to be a systematic defense of the workers, it is why it has articles on the general evolution of the world and articles on the sociology of workers. There was some information about the proletariat in different countries and some of the militants could act as investigative reporters. Socialisme ou Barbarie reacted to the different events and this is why the members acted as journalists. Edwy Plenel showed for instance that Karl Marx was a journalist when he began to comment the international events, especially for the New York Tribune (Plenel, 2008, p. 80). A work can be constituted through different masterpieces of journalism. Castoriadis' style is very singular as Castoriadis wrote many articles that he could rearrange in different books. His way of writing is similar to what happens in Jazz music. There is a creative process that can be rearranged in a different context. His theoretical thoughts developed when he was one of the leaders of Socialisme ou Barbarie were the first part of his masterpiece written in 1975, L'institution imaginaire de la société. Castoriadis wanted to understand the significance of the contemporary world and used some concepts that could have a real explanatory strength. It was possible in some of his articles to have a mixture of 
philosophical references and contemporary politicians. He had a method with specific concepts that needed empirical arguments, in that sense, he was close to what Edgar Morin did in his sociological work (Plenel, 2008, p. 72).

If many studies insist on the content of the avant-guard ideas of Socialisme ou Barbarie, too few scholars were interested in the material conception of the review. Each number was sold out around three new Francs in the fifties and sixties but the review would not have survived with the member fees and the sales. If you calculate the amount by cumulating the inflation, it would have been equivalent to 32 euros in $2015^{2}$. Castoriadis worked as an economist in the international organization OEEC (Organization for European Economic Cooperation) and could support financially the costs of the review. The biography of Castoriadis published by François Dosse in 2014 gave crucial details on how the group and the review evolved in the 1950s and in the 1960s. The group created a specific socialization of outsiders that did not recognize themselves in the French postwar political debate. The review analyzed the evolution of bureaucratic regimes. Once the initial diagnostic accepted by the members, the real idea was to create a group of investigative journalists that could describe and explain some specific social movements occurring in the bureaucratic societies. The militants could verify the validity of the diagnostic thanks to these concrete investigations. Furthermore, many members joined the group and the review after the different breaches inside the USSR. The Hungarian events in 1956 were a source of commitment for many Intellectuals that chose to join the group and the review. In an interview, Daniel Blanchard, explained that he joined the group and the review in 1957 after those events (Greeman, 2014). He added that it was important to remember the overwhelming rhetoric of Marxism and the central figure of the Communist Party. He also gave some interesting details with the idea of "secrecy" that reinforced the cohesion of the group. Castoriadis was himself a clandestine writer using different pseudonyms such as Chaulieu, Coudray and Cardan. He did not have any regular papers when he arrived in France in 1945. He had to wait until 1970 to have regular papers and this was due to the fact that he did not want to be sent back to Greece under the dictatorship of the colonels.

It is also important to know how the review worked. The volume VI (13th year, December 1961-February 1962 , n. 33) is worth being analyzed in its conception. It is written: "theoretical review of the organization Pouvoir Ouvrier, quarterly publication" (Socialisme ou Barbarie, volume VI, pp. 1961-1962). In this number, we have an article of Jean Delvaux on the crisis of Gaullism, then an article of Jean-François Lyotard on the situation in Algeria, an article of Mothé on the young workers, an article of Canjuers on the South-African society and an article of Paul Cardan (one of the pseudonyms for Castoriadis). Then, extracts from other articles, comments on the news can be found in the section "Le monde en question" (Socialisme ou Barbarie, volume VI, 1961-1962, pp. 86-98). In this last section, an analysis of the medias is proposed on how the upheavals in Algeria are dealt with. Some extracts of interviews are transcripted without any comments such as the one of the worker of Nanterre: "What the people of Nanterre think about that": "I am a worker, I do not care about Algeria. If they want the independency, let's give it to them" (Socialisme ou Barbarie, volume VI, 1961-1962, p. 86). The situation of the French farmers during the summer 1961 is also dealt with. It is confronted with the situation of the farmers in the United States thanks to the translation of an article of New-York Herald Tribune in July 1961. This analysis showed a structural problem of farmers in the Western world. The agriculture was too intensive, the overproduction was also a problem and the article referred to the

\footnotetext{
${ }^{2}$ http://france-inflation.com/index.php (Last visit 17 May 2016).
} 
situation in the Nordic countries with the milk problem. The government allocates subventions to the farmers (Socialisme ou Barbarie, volume VI, 1961-1962, p. 87). This is an absurd situation and the review published the testimony of an American worker that was given public subsidies to prevent him from cultivating more corn. This problem is recurrent in all the countries but the review echoed those kinds of problems. The review is in fact divided between strong theoretical analysis and empirical investigations illustrating the contradictions of bureaucratic systems. The situation of the Black people is also analyzed throughout the numbers of Socialisme ou Barbarie.

According to François Dosse, the review and the group were centered around the personality of Castoriadis (Dosse, 2014, pp. 101-117). There is a contrast between the ultra-minority of this Trotskyist tendency and the gigantic task that they assigned themselves. They were working on the Cold War as an illustration of the evolution of a social regime which is bureaucratic capitalism. The members wanted to debate on world problematic and geopolitical relations but their influence was rather limited. The group had its own socialization which means that the members met regularly and were convinced that a better collective future was possible. Their activities were clandestine as they criticized all the Marxist and Trotskyist movements in France. In Paris, the members of the group used to meet in a bar called Le Tambour in the Bastille (Dosse, 2014, p. 101). Some of the members had a different background with people coming from the youth hostel movement such as Alex and Denise Laforgue. The meetings were long and Castoriadis always concluded them with a strong analysis of the evolution of bureaucratic regimes (Dosse, 2014, pp. 103-104). If the group could include some analysis from other periodicals, most of the energy was devoted to their own concepts. Some books influenced the work of the group such as the sociological work of Brown on what happened in American industries (Brown, 1954). There is an interest of the group in the situation in the United States, which largely differs from other leftist reviews.

The most interesting contributions are sociological as they allowed the reader to understand the fundaments of a social institution such as a factory. Daniel Mothé was a member of the group and a worker in Renault. He gave a very accurate testimony on how the work conditions were in this factory. Mothé described the organization of work, the relations between order-takers and sometimes the division of workers, the difficulty for Algerian workers to be accepted by French workers inside the factory (Mothé, 1959). Mothé proposed a description of a milieu that was not known for most of the scholars in social sciences. As a worker and a political activist, he could use his position to make a participant observation.

\section{The Relations Between Political Periodicals}

Socialisme ou Barbarie is a mixture of theoretical assessments and investigative journalism. The group and the review had strong links with some other revolutionary organizations such as Socialism Reaffirmed. Maurice Brinton, one of the cofounders of the movement Socialism Reaffirmed, expressed in different writings a conception close to Castoriadis' main thoughts on socialism (Brinton, 1968). For instance, it is possible to discover a similar conception of relations between order-givers and order-takers in Brinton's thought.

Post-war capitalism has certainly provided more jobs and better paid ones than many may have thought possible. But its drive to subordinate people to the process of production has intensified at an enormous rate. At work, people work, people are reduced more and more to the role of button-pushing lever-pressing machines. In the "ideal" capitalist factory human beings would perform only the simplest, routine tasks. The division of labor would be carried to its extreme. Managers would decide. The workers only comply. (Brinton, 1961). 
The diagnostic is expressed with other words to describe the rationalization of labor in a capitalist society. The ideal-type of a capitalist organization is the complete separation of order-givers and order-takers. If order-takers can just comply and not organize themselves, the organization can go on with the same principles. 1961 is a crucial year in the organization as the review develops its international contacts. There was maybe a need to go over the internal discussions to meet other revolutionary organizations (Gottraux, 1997, p. 251).

In May 1961, a platform of discussion was initiated with Pouvoir ouvrier belge (Belgium), Socialism reaffirmed (Great Britain), Socialisme ou Barbarie and Unita Proletaria (Italy). The conference aimed at redefining the objectives of the struggle against capitalism in the early sixties. There was a deep consciousness of the over bureaucratization of the world with two monstrous types of socialization, the USSR that perverted all kinds of socialist ideas and the capitalist societies that privatize all the social spheres to repress the emancipation of workers. Socialism is self-management of workers. This platform showed at the same time the fragility of those organizations which were revolutionary groups that tried to survive thanks to the publication of a periodical.

The relations of production remain the basis of the class structure of any society. In all countries of the world, these relations are capitalist relations because they are based on wage labor. The wage-earners, both as individuals and as a social group, are expropriated from the means of labor, from the products of labor, and from the control of their own activity. They are concentrated in enterprises of various sizes where they are subjected to the ruthless will of capital, personified in the bureaucratic managerial apparatus. (Socialisme ou Barbarie, 1961).

The international relations that the members had were mainly built through those platforms. In many cases, those platforms showed that the other international groups did not go over the pamphlet form whereas Socialisme ou Barbarie was rather organized as a theoretician review. There were no images and no aesthetics in the review contrary to some other existing reviews. Socialisme ou Barbarie had links in the end of the 1950s with other French reviews such as the review Arguments (1956-1962). Edgar Morin and Claude Lefort who were members of Socialisme ou Barbarie also contributed to this review. The review Arguments had a French and Italian editorial boards. In one of the numbers (June-September 1957), three authors proposed an accurate analysis of the thesis of Socialisme ou Barbarie, Claude Lefort (1957, pp. 19-21), Gérard Genette (1957, pp. 8-12) and Edgar Morin (1957, pp. 12-19). They recognized the originality of the review even though they insisted on the Trotskyist filiation and the critics of imperialism which was common in the leftist circles. They particularly appreciated the deep understanding of the bureaucratic phenomenon which is the search of exclusion of the proletariat from the political decisions. These articles were important as they gave more visibility to the review which was marginalized. The Sovietologist expertise is appreciated by the members of Arguments as the critics of the bureaucratic system were thoroughly analyzed.

Socialisme ou Barbarie shared many common points with the review Internationale Situationniste (1957-1972) on the cultural critic of capitalism. They had the same connections to Solidarity and the movement of self-organized students in Japan, Zengakuren (Dowsey, 1970). Guy Debord had contacts with Socialisme ou Barbarie in the beginning of the 1960s but the relation between both movements was a misunderstanding (Trespeuch, 2009). The Internationale Situationniste created a cultural and aesthetic critic of the consumption society whereas Socialisme ou Barbarie focused more on bureaucratic societies and the evolution of the Russian regime. The Internationale Situationniste had more a literary form than Socialisme ou Barbarie and some of the provocative articles used the pamphlet genre. The Internationale Situationniste organized different international conferences, adopted resolutions and had circles in different countries, they seemed to have more 
political influence than Socialisme ou Barbarie during that time (Internationale Situationniste, 1960). They had a political and artistic goal as a new artistic revolution would create the conditions for a new social contract. They inserted cartoons, pictures and objects in the different reviews which was not the case for Socialisme ou Barbarie. They quoted some sentences of Castoriadis (Internationale Situationniste, 1960, p. 47) but they criticized the evolution of the review and the group. Socialisme ou Barbarie could not really give birth to an international organization with members in different countries, they had some limited platforms, which can explain the disappearance of the group.

\section{Conclusion}

Socialisme ou Barbarie is an example of how a militant review and group turned to be an investigative journal relating theoretical views to deep sociological investigations. There is, in some libertarian writings, an anticipation of the transformation of investigative journalism and this review is an illustrating example of that tendency. The networks of revolutionary periodicals, the translation of other articles of the same trend also show the evolution of a theoretical review towards a real investigative journalism. However, there is a difference between all these leftist periodicals. Some of them can be reduced to pamphlets whereas the other ones like Socialisme ou Barbarie proposed empirical illustrations of a strong thesis. Castoriadis' view was prevailing in this group, there was an attempt to create a political force based on this analysis. The misunderstanding in the group explained why Socialisme ou Barbarie was reduced to a kind of investigative journalism. The members of this group were engaged in other periodicals, they could import the specific views of Socialisme ou Barbarie on bureaucratic societies in other periodicals. Like other leftist groups and periodicals, the strategic issue could be source of division. Can a group of strong theoreticians be a revolutionary party when it criticized the bureaucratic forms of political organizations? There was here a dilemma that could be found in other radical left periodicals. The quality of the editorials and the research made in most of the articles reflect this investigative will. The members of Socialisme ou Barbarie reported many breaches inside the bureaucratic societies, they acquired a good expertise on the evolution of Russian regime and echoed many autonomous movements.

\section{References}

Bird, S. E. (2010). The anthropology of news and journalism, global perspectives. Indiana: Indiana University Press.

Brinton, M. (1961). Revolutionary organization. Retrieved from https://www.marxists.org/archive/brinton/1961/05/organization.htm

Brinton, M. (1968). For workers' power, the selected writings of Maurice Brinton. Edinburgh: AK Press.

Brown, J. A. C. (1954). The social psychology of industry. London: Penguin.

Castoriadis, C. (1973). La Société bureaucratique (The bureaucratic society). In Les Rapports de production en Russie (Productive relations in Russia). Paris: Union Générale d'Éditions.

Castoriadis, C. (1997). The Castoriadis reader. Cornwall: Blackwell Publishers.

Chaulieu, P. (1949). Les Kohlkoz pendant la guerre (The Kohlkoz under the war). Socialisme ou Barbarie, 4, 5-18.

Chiclet, C. (1990). Agi Stinas, Mémoires. Un révolutionnaire dans la Grèce du XXe siècle (AgiStinas, Memoirs: A revolutionary militant in the 20th century Greece). CEMOTI, 10, 117-118.

Cramerotti, A. (2009). Aesthetic journalism: How to inform without informing. Bristol: Intellect.

Curtis, D. A. (1997). The Castoriadis reader. Oxford: Blackwell Publisher.

Dosse, F. (2014). Castoriadis, une vie (Castoriadis' life). Paris: La Découverte.

Dosse, F. (2015). Castoriadis: un titan de l'esprit (Castoriadis, a titan of the spirit). Retrieved from https://www.youtube.com/watch?v=xudPDfTKrfs 
Dowsey, S. (1970). Zengakuren: Japan's revolutionary students. Berkeley: Ishi Press.

Genette, G. (1957). Notes sur Socialisme ou Barbarie (Notes on Socialism or Barbarism). Arguments, 4, 8-12.

Gottraux, P. (1997). Socialisme ou Barbarie: un engagement politique et intellectuel dans la France d'après-guerre (Socialismor Barbarism: A political and intellectual engagement in the postwar France). Paris: Payot.

Greeman, R. (2014). Interview with former members of Socialisme ou Barbarie, Helen Arnold, Daniel Blanchard. Retrieved from https://vimeo.com/85893170

Hurdley, R. (2013). Home, materiality, memory and belonging: Keeping culture. London: Palgrave Macmillan.

Jollivet, S., Rosengren, M., \& Premat, C. (2011). Destins d'exilés. Trois philosophes grecs à Paris: Kostas Axelos, Cornelius Castoriadis et Kostas Papaïoannou (Exiles' destinies. Three Greek philosophers in Paris: Kostas Axelos, Cornelius Castoriadis and Kostas Papaïoannou). Paris: Manuscrit.

Lefort, C. (1957). Sur l'article d'Edgar Morin (About Edgar Morin's article). Arguments, 4, 19-21.

Lefort, C. (1971). Éléments d'une critique de la bureaucratie (Elements of a critic of bureaucracy). Paris: Gallimard.

Lyotard, J. F. (1989). La Guerre des Algériens: Écrits 1956-1963 (The war of Algerians: Writings 1956-1963). Paris: Galilée.

Lyotard, J. F. (1990). Pérégrinations. Paris: Galilée.

Marchetti, D. (2000). Les révélations du "journalisme d'investigatio" (The revelations of "investigative journalism”). In Actes de la recherché en sciences sociales (pp. 30-40).

Memos, C. (2014). Castoriadis and critical theory: Crisis, critique and radical alternatives. London: Palgrave Macmillan.

Milliex, R. (1996). L'Institut français d’Athènes, fils spirituel de l'École française (The French Institute of Athens, spiritual son of the French school). In Bulletin de correspondance hellénique (pp. 69-82).

Morin, E. (1957). Solécisme ou Barbarie (Solecism or Barbarism). Arguments, 4, 8-12.

Mothé, D. (1959). Journal d'un ouvrier (1956-1958) (A worker's diary (1956-1958)). Paris: Minuit.

Papaïoannou, K. (1969). Les idées contre l'idéologie: Formes et degrés de la débolchevisation (Ideas versus ideologies: Forms and degrees of unbolshevism). Revue Françise de Science Politique, 1, 46-62.

Plenel, E. (2008). Face au sphinx: Edgar Morin et le journalisme. Communications, 1, 71-86.

Premat, C. (2004). A new generation of Greek intellectuals in Postwar France. In J. Bourg (Ed.), New perspectives on the intellectual and cultural history of Postwar France (pp. 103-123). Lexington: Lexington Books.

Raflin, M. F. (2005). Socialisme ou Barbarie: du vrai communisme à la radicalité (Socialism or Barbarism: From true Communism to radicality). Paris, Institut d'études politiques: PhD.

Socialisme ou Barbarie. (1961). Retrieved from https://libcom.org/library/\%EF\%BB\%BFsocialism-or-barbarism-1962

Trespeuch, A. (2009). L'Internationale situationniste: d'autres horizons de révolte (The situationist international: Other paradigms of revolt). In Matériaux pour l'histoire de notre temps (pp. 10-15). 